\title{
Research on Role Cognition and Employment Strategy of Rural Female Laborers in Sichuan, China
}

\author{
Yue Shui ${ }^{1,2}$, Dingde $\mathrm{Xu}^{3}$ and Shaoquan Liu ${ }^{1, *}$ \\ 1 Institute of Mountain Hazards and Environment, Chinese Academy of Sciences, Chengdu 610041, China; \\ shuiyue16@mails.ucas.ac.cn \\ 2 University of Chinese Academy of Sciences, Beijing 100049, China \\ 3 Sichuan Center for Rural Development Research, College of Management of Sichuan Agricultural \\ University, Chengdu 611130, China; dingdexu@sicau.edu.cn \\ * Correspondence: liushq@imde.ac.cn; Tel.: +86-13072807630
}

Received: 14 February 2019; Accepted: 15 March 2019; Published: 21 March 2019

\begin{abstract}
Paying attention to role cognition and the employment strategies of female rural laborers has great significance for the improvement of the status of women and the rational transfer of labor forces. However, there are few studies of role cognition amongst the rural female labor workforce. There is even less research on the relationship between role cognition and employment transfer strategies. In this study, a survey of 425 female rural laborers in the Sichuan Province, China, was conducted to construct a role-based cognitive scale in order to measure the cognitive levels of subjective ability, self-role expectations and role conflicts. This paper divides employment strategy into four aspects: Actual workplaces, workplace preferences, actual industries, and industry preferences. An unorganized multi-classification logistic regression model was constructed in order to explore the relationship between the role cognition and employment strategy selections. The results indicated that there was a significant difference between employment expectations and realities. Rural females with more equal modern role cognition had a higher expectation of employment. Meanwhile, those who had a strong feeling of role conflicts, tended to work in other places and choose secondary and tertiary industries. However, in reality, most were unemployed. The conflict of roles clearly restricts employment options of the rural female workforce. This study enhances our understanding of the relationship between the perceptions of the Chinese female labor workforce and the employment strategies used. The findings can help to provide a reference for guiding employment policies and the flow of the female labor workforce.
\end{abstract}

Keywords: role cognition; women; rural laborers; employment strategy; China

\section{Introduction}

Since the reform and opening up of China's economy, there has been a period of rapid development. With the continuous deepening and expansion of urbanization in China, the rapid economic development has provided a large number of jobs for migrant workers. Driven by economic interests, many laborers go out to work. and out-migrating for work has become the main means for migrant workers to maintain their livelihoods [1-5]. According to statistics, the total number of migrant workers in China reached 280 million in 2017. Among them, there were 168.84 million out-migrant workers, which accounted for $60.85 \%$ of the total number of migrant workers. Meanwhile, the wage income of famers accounts for $40 \%$ of per capita disposable income in China [6-8]. China is a traditional agricultural country, and for a long time, the traditional pattern of gender division of labor in rural China was "breadwinning men and homemaking women" or "farming men and weaving women" [9]. With the development of the economy and changes in social concepts driven by 
economic interests, more and more rural females go out to work. Based on statistics, since the reform and opening up, the proportion of rural female migrant workers in China has increased from $25 \%$ to $37 \%$, which is an increase of $12 \%$ [9]. However, with the massive outflow of rural female laborers, the role of females in "taking care" of the family is gradually weakening, and problems are arising with regard to support of the elderly and the raising of children $[10,11]$. According to statistics, there are currently more than 60 million children left behind, and 194 million elderly people aged over 60 years also left behind in rural China [12]. Because of the substantial national support for rural areas, as well as the abundant social capital investment in rural industries, the economy of some rural areas has in recent years developed rapidly, which has created a lot of jobs for laborers. In this context, the growth of rural female migrant workers in some areas is slowing down, presenting a trend of gradual backflow. For example, Han found that the proportion of rural female migrant workers has gradually dropped from 34.9\% to 34.5\% in the Sichuan Province during 2009 to 2016 [13]. Some rural female laborers have chosen to work nearby in order to strike a balance between family and work. Rural female laborers play an important balance and adjustment role in solving the problem of raising the children left behind, and of supporting the elderly in China [14,15].

Chinese women are traditionally considered to be the "homemakers"; however, with the massive outflow of rural female laborers, social roles have shifted, with women moving from the single role of family to the dual roles of career and family. Correspondingly, the social cognition of females' roles has tended to gradually become equal [16-18]. However, due to the traditional cognition of female roles, some female laborers still suffer many inequalities in their families, which are mostly manifested as low status, no control over family property, and so on. The more prominent difficulty is that due to facing conflict between family and career roles, many rural females can only choose to either work nearby, or to engage in part-time work, and many must give up out-migrating for work. Furthermore, employed females are often forced to adjust their employment expectations because of their need to take care of their family, which also leads to unfree employment and the migration of rural females [19,20], as well as disparity between employment expectations and actual employment selections. Subjective ability cognition and self-role expectations affect the career expectations of females, while the conflict between roles restricts the employment selection of rural females; thus, the influence of women's role cognitions on their employment participation is widespread [21]. However, few quantitative studies have systematically explored the differences between the employment expectations and the actual employment selections of rural females, as well as the relationship between role cognition and employment strategy selections. This provides room for the development of the current study.

Role cognition, as discussed in the current study, is an individual's cognition and understanding of the behavior norms of their own roles in a social culture. The current study belongs to the category of research of the attitudes towards sex-roles in western countries. Beginning in the 19th century, the study of female role cognition mainly used scales to measure people's attitudes towards women's rights, roles and responsibilities. The research methods have undergone a transition from qualitative research to quantitative research, and several significant achievements have been made, which can provide useful reference for this study. There are few studies of sex-role attitudes in China; the studies in western countries have been more mature, presenting the characteristics of diverse measurement scales (such as the Attitudes Toward Women Scale (AWS), Sex-Role Egalitarianism Scale (SRES), and Neosexism Scale (NS)) and complicated research concepts, as well as changes in sex-role attitudes over time. With the improvement in sex-role positioning measurement tools, many scholars have begun to pay attention to the factors influencing sex-role attitudes. Compared to males, many studies have shown that females have more modern sex-role attitudes [17], and age is a key factor affecting sex-role cognition [22,23], whereas people with higher educational levels and greater labor participation have more equal sex-role orientations [24]. On the one hand, the diversity of measurement scales reflects that researchers are dissatisfied with the existing studies and measures; this is conducive to promoting the development of sex-role research in a deeper and broader direction, but it is not helpful for researchers conducting regional and cultural comparisons, as it is not clear whether these scales are suitable for 
cross-cultural research. On the other hand, the diversity of the scales shows that traditional sex-role measurement scales cannot adapt to development over time, and need to be revised. Due to the dual structure of China's urban and rural areas, the employment market environment in western countries is remarkably different from that in China. Thus, there are certain differences in role cognition and its influencing factors between Chinese females and western females. Therefore, this study takes into account the actual situation of China's female laborers, combining the research results of "family-work conflicts" with the study of sex-role attitudes to construct a new scale, in order to better measure role cognition among females in China.

With the increasing social concern regarding female employment transfer, some scholars have begun to focus on the correlation between women's sex-role positioning and their employment. Specifically, Judge et al. found that a traditional sex-role orientation has a positive effect on male income, and a slight negative impact on female income [21]. Corrigall reported that, compared with females with more traditional attitudes, females with more equal attitudes take different actions, seek higher education, work harder and eventually engage in higher-income industries [25]. Wu studied the career ambitions of middle-level management women, finding that sex-role attitudes were the most important prerequisite for middle-level management women's careers, and were significantly correlated with career expectations [26]. Most studies have been conducted from a qualitative point of view; few studies have quantitatively examined the disparity between women's role cognition and their employment expectations, including the relationship between employment locations and career selections as well as expectations. This study will address these deficiencies.

Most of China's employment transfer population is in rural areas. According to The Report on the Situation of Human Resources in China [27], there are still 100 million laborers that need to be transferred in rural China. Because of the differences in the level of economic development and concept between rural and urban area, there may be greater conflict between rural women's need and/or want to out-migrate for work and their role need and/or want to take care of their family, and the problems of raising the left-behind children and supporting the elderly are more prominent. The existing studies on role cognition in China and all over the world have mostly focused on female undergraduates, different religious and cultural groups and professional women [28-30], with a lack of the concern for rural females. The issues concerning "agriculture, countryside and farmers" have always been fundamental issues that affect the national economy and people's livelihood, and female laborers are key to solving the problem of raising the left-behind children, and supporting the elderly in rural areas. Thus, based on self-cognition of rural female roles, this study constructs models for rural female role positioning, and investigates the quantitative relationship between role cognition and female employment. The findings of this study will contribute to promoting rural women's rational and orderly employment transfer, rural modernization and rural revitalization.

\section{Data and Methods}

\subsection{Research Area and Data Sources}

The data used in this study are mainly from the rural household survey conducted by China's Rural Development Survey Team in Sichuan Province in April 2016. Located in southwestern China, the Sichuan Province is upstream of the Yangtze River. It covers $486,052 \mathrm{~km}^{2}$ and has a population of 82.04 million, with 42.92 million engaged in agricultural production. The annual net income of farmers in this province is 10,247 Yuan, which is $10.2 \%$ lower than the 2014 national average [6].

The data used in this study primarily came from a survey on women's role cognition and employment selections, and a survey of rural households conducted by China's Rural Development Investigation Group in Sichuan Province, in April 2016. The survey of women's role cognition and employment selections primarily investigated role cognition (including subjective ability cognition, self-role expectations and role conflict cognition) and employment selections (including employment 
expectations and actual employment selections), while the survey of rural households primarily investigated the basic structure, income, etc. of women's families.

The survey sample was determined using a combination of stratified sampling and equal probability random sampling. According to the research by Rozelle [31], counties in Sichuan Province were divided into five categories by the industrial output per capita. One sample county was randomly selected from each group. Five counties were selected from the total of 181 counties. The same method was applied to the towns in each county according to their industrial output per capita. All towns in the sample county were divided into two groups. One town was randomly selected from each group, producing a random selection of ten towns. Furthermore, two villages from the sample town and 20 farmers were selected according to the roster with reference to a random number chart. According to the above process, a total of 400 rural household questionnaires and 20 village questionnaires were obtained. In order to obtain the female samples required for this study, the study further investigated the female of 18-65 years old among the 400 sample households, and obtained a total of 482 female samples. After deleted the samples with incomplete information, 425 valid samples were obtained. The maps of the spatial locations of the sample villages are shown in Figure 1.

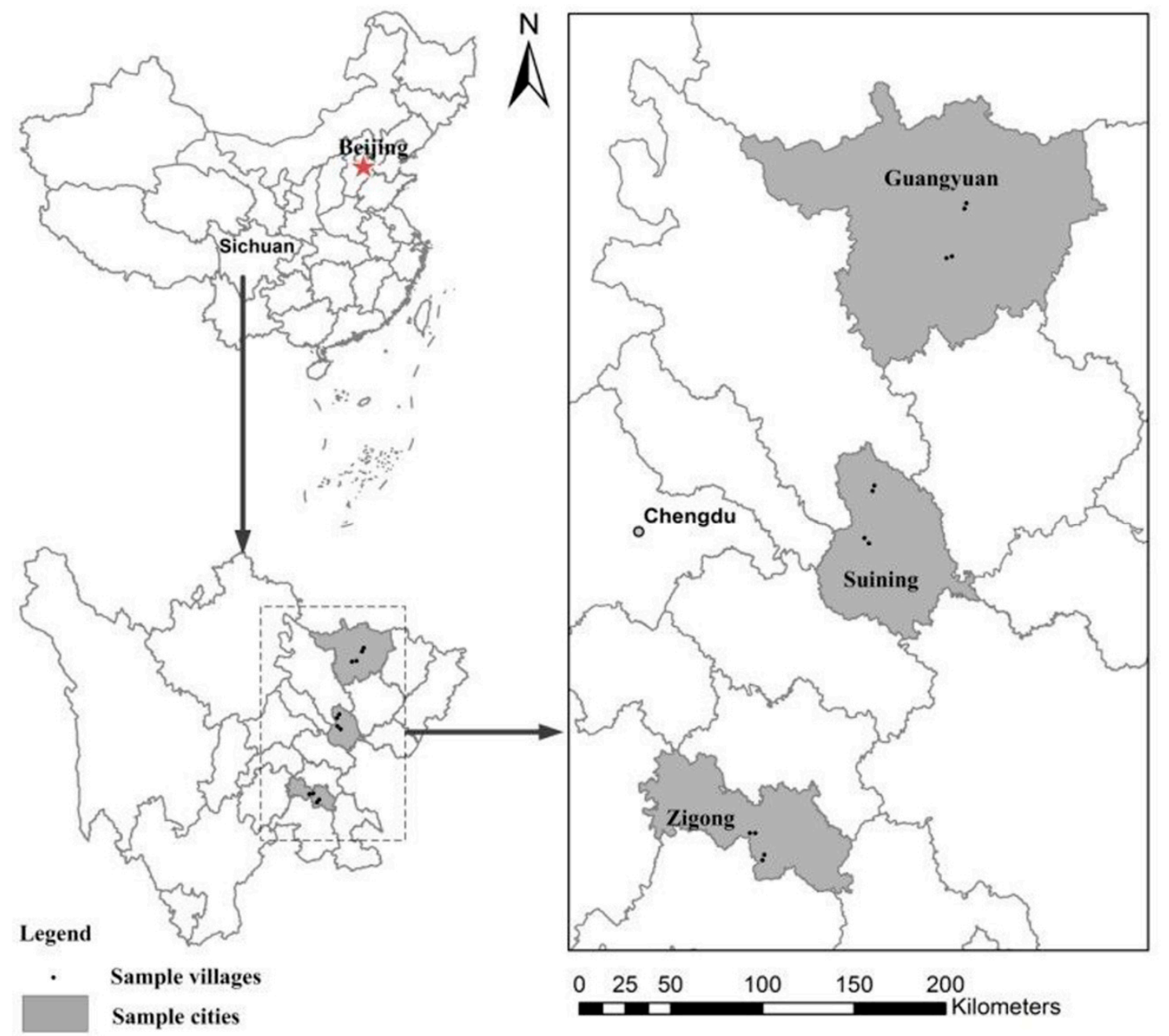

Figure 1. Locations of sample villages. 


\subsection{Variables}

\subsubsection{Dependent Variables}

This study mainly explored the influence of role cognition on employment strategy selections among rural female laborers. In order to provide further insight, employment strategy selections of rural female laborers were divided into four aspects: Actual employment industry, employment industry tendency, actual employment location and employment location tendency. In the questionnaires, consistent with the current researches [3,9], on industry division, rural women's employment industries were subdivided into five categories: "staying at home/unemployment", "farming", "secondary industry", "tertiary industry I" and "the tertiary industry II". In addition, employment locations were divided into three categories: "in the county", "in other counties of the province" and "in other provinces".

\subsubsection{Independent Variables}

Role cognition of rural females was the core independent variable in this study. Role cognition is a subjective judgment, and its measurement is different from the indicator of objective gender equality; thus, it is advisable to adopt a Richter scale, which is a classical method of measuring subjective attitudes in psychology. In such questionnaires, it is common practice to design a series of judgment statements on gender equality attitudes and to ask the participants to endorse one of five response options: "complete agreement", "basic agreement", "unable to judge", "partial disagreement" and "disagreement", which correspond to an indicator score of " $1-5$ ". Higher scores suggest that the respondents have higher subjective ability cognition and higher self-role expectations, or perceive role conflicts more clearly. Based on the theory of social gender, as well as the related theories of sex-role attitudes and family-work conflicts, as discussed in the studies of Harris, Yang and $\mathrm{Xu}[17,32,33]$, this study divided the compositional dimensions of role cognition of rural female laborers into three aspects: Subjective ability cognition, self-role expectations and role conflict cognition. Each aspect included three kinds of measurement indicators, while each indicator comprised three statements to be judged, with corresponding indicator values (see Table 1). The sum of the three indicator scores constitutes the total score for role cognition; higher scores indicate that the respondent's role cognition is more inclined to be non-traditional. The selection of control variables was informed from the current studies [33-35], taking into account the influence of rural women's personal characteristics, family characteristics and village characteristics on their employment strategy selections. Personal characteristics consisted of age, marital status, and educational level. Family characteristics primarily included whether there were elderly people or children in the family, while community characteristic were characterized by the home location in the rural area, namely, the distance to the nearest county center.

Table 1. The design of the scale for measuring cognition of family-work role conflicts.

\begin{tabular}{|c|c|c|}
\hline $\begin{array}{l}\text { Compositional } \\
\text { Dimensions }\end{array}$ & Measurement Indicators & Statements to Be Judged \\
\hline $\begin{array}{l}\text { Subjective ability } \\
\text { cognition }\end{array}$ & $\begin{array}{l}\text { Cognition of his or her own } \\
\text { employment ability, including skill } \\
\text { diversity, skill level, psychological } \\
\text { adaptation, pressure resistance } \\
\text { capability, etc. }\end{array}$ & $\begin{array}{l}\text { (1) Since ancient times, males have been the } \\
\text { breadwinners } \\
\text { (2) Compared with males, female migrant } \\
\text { workers suffer greater stress and psychological } \\
\text { burdens } \\
\text { (3) If you go out to work, you can well coordinate } \\
\text { the conflicts between the family and the work. } \\
\text { (The scores of the above three sentences are } \\
\text { added up, and the resultant score ranges between } \\
3-15 \text { points) }\end{array}$ \\
\hline
\end{tabular}


Table 1. Cont.

\begin{tabular}{|c|c|c|}
\hline $\begin{array}{l}\text { Compositional } \\
\text { Dimensions }\end{array}$ & Measurement Indicators & Statements to Be Judged \\
\hline $\begin{array}{l}\text { Self-role } \\
\text { expectations }\end{array}$ & $\begin{array}{l}\text { Expectations for social roles, } \\
\text { family roles and professional roles }\end{array}$ & $\begin{array}{l}\text { (1) Females should focus on taking care of the } \\
\text { family } \\
\text { (2) For household income/livelihoods, females } \\
\text { should also go out to work } \\
\text { (3) When there are certain conflicts between } \\
\text { taking care of the family and going out to work, } \\
\text { females should make certain sacrifices and take } \\
\text { care of their families at home } \\
\text { (The scores of the above three sentences are } \\
\text { added up, and the resultant score ranges between } \\
3-15 \text { points.) }\end{array}$ \\
\hline Role conflicts & $\begin{array}{l}\text { Cognition of the conflicts between } \\
\text { family roles and professional roles, } \\
\text { cognition of the conflicts between } \\
\text { practical roles and expected roles, } \\
\text { cognition of the conflicts between } \\
\text { role expectations and subjective } \\
\text { abilities }\end{array}$ & $\begin{array}{l}\text { (1) You often dispute with your spouse/families } \\
\text { over money } \\
\text { (2) You often dispute with your spouse/families } \\
\text { over work } \\
\text { (3) You often dispute with your spouse/families } \\
\text { over taking care of the family } \\
\text { (The scores of the above three sentences are } \\
\text { added up, and the resultant score ranges between } \\
\text { 3-15 points.) }\end{array}$ \\
\hline
\end{tabular}

\subsection{Model Methods}

The dependent variables of "actual employment location", "employment location tendency", "actual employment industry" and "industry selection tendency" are unordered multi-classification variables, so this study used unordered multi-classification logistic regression models to explore the relationship between role cognition and employment strategy selections of rural females. The model formula is shown below:

$$
\ln \left(\frac{p_{i}}{1-p_{i}}\right)=\alpha_{i}+\sum_{j=1}^{8} \beta_{i j} X_{i j}+\varepsilon_{i}
$$

where, $i$ represents rural female laborers; $j$ indicates the influencing factors (including independent variables and control variables); $p_{i}$ denotes the probability of rural women's selections for the actual employment location, the employment location tendency, the actual employment industry and the industry selection tendency; $X_{i j}$ refers to the independent variables in the model, namely the influencing factors of subjective ability cognition, self-role expectations and role conflict cognition; $\beta_{i j}$ is the coefficient estimation value of influencing factors, meaning the variation in the natural logarithm value of the odds ratio resulting from a one-unit increase in the value of the influencing factor $j$ when the values of other influencing factors remain unchanged; $\alpha_{i}$ is the constant term; $\varepsilon_{i}$ is the random error.

\section{Econometric Results}

\subsection{Descriptive Statistical Analysis}

As indicated from the descriptive statistics (see Table 2), in terms of personal characteristics, the average age of rural female laborers from the sample households was about 45 years old with an even distribution. About $90 \%$ of the rural female laborers were married. Meanwhile, the overall educational level was relatively low, and the average and maximum number of years of education were 6.21 years and 15 years (bachelor degree), respectively; approximately $85 \%$ of the rural female laborers only had a junior high school degrees or lower. With regard to family characteristics, there were elderly people or children in most rural female laborers' families. Concerning social characteristics, the distance from the nearest township ranged from $0.1 \mathrm{~km}$ to $40.8 \mathrm{~km}$, but most families were less than $10 \mathrm{~km}$ away from the nearest townships. The regional distribution of rural females is relatively uniform. 
Table 2. Descriptive statistics for the variables.

\begin{tabular}{|c|c|c|c|c|c|}
\hline Variable & Definition and Assignment & Min & Max & Mean & SD \\
\hline \multicolumn{6}{|c|}{ Explanatory variables } \\
\hline \multicolumn{6}{|c|}{ Role cognition variables } \\
\hline SAC & Subjective ability cognition & 3 & 14 & 8.03 & 1.9 \\
\hline SRE & Self-role expectations & 3 & 15 & 8.43 & 1.91 \\
\hline RCC & Role conflict cognition & 3 & 15 & 7.59 & 2.68 \\
\hline \multicolumn{6}{|c|}{ Control variables } \\
\hline \multicolumn{6}{|c|}{ Individual characteristics } \\
\hline EDU & Years of education & 0 & 15 & 6.21 & 4.27 \\
\hline MAR & MAR = 1 for married, MAR = 2 for unmarried & 1 & 2 & 1.90 & 0.31 \\
\hline AGE & Age of rural women migrant laborers & 18 & 64 & 44.83 & 12.93 \\
\hline \multicolumn{6}{|c|}{ Household characteristics } \\
\hline OAC & $\begin{array}{l}\mathrm{OAC}=0 \text { for none, } \mathrm{OAC}=1 \text { for only children in } \\
\text { the household, } \mathrm{OAC}=2 \text { for only elderly in the } \\
\text { household, } \mathrm{OAC}=3 \text { for both children and } \\
\text { elderly in the household }\end{array}$ & 0 & 3 & 1.45 & 1.02 \\
\hline \multicolumn{6}{|c|}{ Community characteristics } \\
\hline DISC & Distance to the nearest county $(\mathrm{Km})$ & 0.10 & 40.80 & 5.19 & 4.92 \\
\hline FC & $\begin{array}{l}\mathrm{FC} 1=\text { from county } 1, \mathrm{FC} 2=\text { from county } 2, \\
\mathrm{FC} 3=\text { from county } 3, \mathrm{FC} 4=\text { from county } 4, \\
\mathrm{FC} 5=\text { from county } 5\end{array}$ & 1 & 5 & 3.04 & 1.47 \\
\hline
\end{tabular}

Note: Elderly individuals in the household were considered to be aged 65+ years; children in the household were classified as those aged 6 years and under.

\subsection{Analysis of the Differences Between Employment Expectations and Actual Employment Strategy Selections} of Rural Females

Table 3 shows the descriptive statistical analysis and the difference test results of actual employment selections and the employment expectations of rural females. In terms of the employment industry, the proportion of rural women engaging in farming was the highest; about $55 \%$ of the rural female laborers were unemployed at home or engaged in farming, while about $35 \%$ and $10 \%$ of rural females engaged in tertiary industry and secondary industry, respectively. The t-test results revealed that there was a significant difference between the actual employment industries and the industry selection expectations of rural females $(p<0.001)$. Specifically, the average value of rural women's actual employment industries was significantly lower than that of their industry selection expectations, indicating that, compared with farming at home, rural females are more willing to engage in secondary and tertiary industries. Similarly, the average value of rural women's actual employment locations was significantly lower than that of their employment location expectations $(p<0.05)$. The reasons for these differences are complicated. This study assumes that rural women's cognition of the conflicts between family and work roles is an important factor affecting their employment strategy selections. Thus, more detailed analysis was conducted using unordered multi-classification logistic regression models.

Table 3. The $t$-test results of actual employment and employment expectations of rural female laborers.

\begin{tabular}{|c|c|c|c|c|}
\hline Variables & Definitions & $\begin{array}{l}\text { Average } \\
\text { Value }\end{array}$ & SD & $t$-Value \\
\hline $\begin{array}{l}\text { Employment } \\
\text { industry }\end{array}$ & \multirow{2}{*}{$\begin{array}{c}0=\text { unemployment } / \text { staying at home, } \\
\begin{array}{c}1=\text { farming }, 2=\text { secondary industry, } \\
3=\text { tertiary industry I, } \\
4=\text { tertiary industry II }\end{array}\end{array}$} & 1.83 & 1.44 & \multirow[t]{2}{*}{$12.54^{* * *}$} \\
\hline $\begin{array}{l}\text { Industry selection } \\
\text { tendency }\end{array}$ & & 2.78 & 0.84 & \\
\hline Employment location & \multirow{2}{*}{$\begin{array}{l}1=\text { in the county, } 2=\text { in other counties of } \\
\text { the province, } 3=\text { in other provinces }\end{array}$} & 1.35 & 0.72 & \multirow{2}{*}{-2.12 * } \\
\hline $\begin{array}{l}\text { Employment location } \\
\text { selection tendency }\end{array}$ & & 1.44 & 0.75 & \\
\hline
\end{tabular}

Note: ${ }^{*} p<0.1,{ }^{* * *} p<0.01$. 


\subsection{Econometric Model Results}

The research objective was to explore the relationship between role cognition and employment strategy selections of rural females. In order to achieve this goal, two unordered multi-classification logistic regression models were constructed (see Tables 4 and 5). Table 4 shows the unordered multi-classification logistic regression model for the relationship between role cognition and both employment location and employment tendency, as well as industry selection and industry tendency. Table 5 presents the results obtained by adding the control variables, of rural women's personal characteristics, family characteristics and village characteristics to the model.

Concerning the influence of role cognition on actual employment location and employment location tendency, in terms of the three dimensions of role cognition, it appears that role cognition is not related to actual employment location, while role cognition is significantly positively correlated with employment location tendency; specifically, subjective ability cognition and role conflict cognition were positively related to employment location tendencies of rural female laborers. Compared with tending to work in the county, with every one-unit increase in subjective ability cognition, the probability that rural females tended to work in other counties of the province increased by $19.4 \%$, and with every one-unit increase in role conflict cognition, the probabilities of rural women tending to work in other counties of the province and in other provinces increased by $16.45 \%$ and $12.7 \%$, respectively. These results show that rural females who have higher self-ability cognition and perceive role conflicts more clearly, are more inclined to choose to work in other counties or other provinces far away from their hometowns. Rural females whose role cognition is more inclined to be non-traditional have a stronger desire to go out to work in areas far away from their hometowns, and in the face of conflict between family roles and social roles, rural females are more willing to realize their social roles.

Regarding the influence of role cognition on actual employment industry, compared with selecting farming, with every one-unit increase in subjective ability cognition, the probability that rural females engaged in tertiary industry I increased by $23.3 \%$, and with every one-unit increase in self-role expectations, the probabilities of rural women engaging in secondary industry and tertiary industry I increased by $29.2 \%$ and $25.6 \%$, respectively. Further, with every one-unit increase in role conflict, the probability that those rural females were unemployed at home increased by $14 \%$. In terms of the influence of role cognition on industry selection tendency, subjective ability cognition was not related to industry selection tendency, whereas self-role expectation and role conflict cognition (especially self-role expectation) were positively correlated with industry selection tendency. Compared with farming, with every one-unit increase in self-role expectation, the probability of rural women tending to work in secondary industry, tertiary industry I and tertiary industry II increased by $41 \%, 47 \%$ and $34.5 \%$, respectively, whereas with every one-unit increase in role conflict cognition, the probability of rural females tending to be unemployed at home decreased by $35.1 \%$. Rural females with high expectations for their professional roles and social roles are unwilling to be unemployed at home or deal with farming, and they are more willing to work in secondary and tertiary industries to achieve their own values and self-expectations, as well as to increase their own and their families' economic benefits. More importantly, through comparison of the results on the influence of role cognition on actual employment industry and employment location tendency, it can be seen that when perceiving conflicts between family roles and social roles, rural females are more willing to achieve their social roles (work in areas far away from their hometowns), but in fact, they generally choose to stay at home and take care of the elderly and children. As mentioned above, because of having to take care of the family, females are often unable to go out to work, and their actual employment industries and locations are inconsistent with their expectations. The conflicts between family roles and social roles obviously restrict women's employment selections. 
Table 4. Unordered multi-classification logistic regression model.

\begin{tabular}{|c|c|c|c|c|c|c|c|c|c|c|c|c|}
\hline \multirow{2}{*}{$\begin{array}{c}\text { Variable } \\
\text { RC }\end{array}$} & \multicolumn{2}{|c|}{$\begin{array}{l}\text { Employment } \\
\text { Location } \\
\text { (OR) }\end{array}$} & \multicolumn{2}{|c|}{$\begin{array}{c}\text { Employment } \\
\text { Location Selection } \\
\text { Tendency } \\
\text { (OR) }\end{array}$} & \multicolumn{4}{|c|}{$\begin{array}{l}\text { Employment Industry } \\
\text { (OR) }\end{array}$} & \multicolumn{4}{|c|}{$\begin{array}{l}\text { Industry Selection Tendency } \\
\text { (OR) }\end{array}$} \\
\hline & $\mathrm{HP}$ & $\mathrm{OHP}$ & $\mathrm{HP}$ & $\mathrm{OHP}$ & PI & SI & TI1 & TI2 & PI & SI & TI1 & TI2 \\
\hline \multirow{2}{*}{ SAC } & 0.170 & 0.069 & $0.254^{* * *}$ & -0.028 & $0.208^{* *}$ & 0.144 & $0.280^{* *}$ & $0.226^{* * *}$ & -0.246 & 0.011 & 0.104 & 0.246 \\
\hline & & & $(1.290)$ & $(1.231)$ & & $(1.323)$ & $(1.254)$ & & & & & \\
\hline \multirow{2}{*}{ SRE } & 0.168 & 0.222 ** & 0.135 * & $0.200^{* *}$ & $0.164 *$ & $0.369^{* * *}$ & $0.322^{* * *}$ & $0.224^{* * *}$ & -0.172 & $0.391^{* * *}$ & $0.363^{* * *}$ & $0.415^{* * *}$ \\
\hline & & (1.249) & (1.145) & $(1.220)$ & $(1.178)$ & (1.446) & $(1.380)$ & $(1.251)$ & & $(1.479)$ & $(1.438)$ & (1.515) \\
\hline \multirow{2}{*}{ RCC } & 0.046 & 0.023 & $0.118^{* *}$ & $0.094^{* *}$ & $0.097 *$ & 0.189 & 0.018 & 0.000 & $-0.303^{* * *}$ & -0.105 & -0.065 & -0.094 \\
\hline & & & (1.125) & (1.010) & (1.102) & & & & $(0.739)$ & & & \\
\hline
\end{tabular}

Note: ${ }^{*} p<0.1,{ }^{* *} p<0.05,{ }^{* * *} p<0.01$. OR $=$ Odds ratio. Stata14.0 software was used to analyze the data. RC $=$ Role cognition; SAC $=$ Subjective ability cognition; SRE $=$ Self-role expectations; $\mathrm{RCC}=$ Role conflict cognition; $\mathrm{HP}=$ Home province, but outside of home county; OHP = Outside of home province. $\mathrm{PI}=\mathrm{Unemployment} /$ staying at home, $\mathrm{SI}=\mathrm{Secondary}$ industry, TI1 = Tertiary industry I, TI2 = Tertiary industry II

Table 5. Robust unordered multi-classification logistic regression model.

\begin{tabular}{|c|c|c|c|c|c|c|c|c|c|c|c|c|}
\hline \multirow[t]{2}{*}{ Variable } & \multicolumn{2}{|c|}{$\begin{array}{l}\text { Employment Location } \\
\text { (OR) }\end{array}$} & \multicolumn{2}{|c|}{$\begin{array}{c}\text { Employment Location } \\
\text { Selection Tendency } \\
\text { (OR) }\end{array}$} & \multicolumn{4}{|c|}{$\begin{array}{l}\text { Employment Industry } \\
\text { (OR) }\end{array}$} & \multicolumn{4}{|c|}{$\begin{array}{l}\text { Industry Selection Tendency } \\
\text { (OR) }\end{array}$} \\
\hline & HP & OHP & HP & OHP & HOM & SI & TI1 & TI2 & HOM & SI & TI1 & TI2 \\
\hline \multicolumn{13}{|c|}{ Role Cognition } \\
\hline SAC & 0.085 & 0.036 & $\begin{array}{l}0.177^{* *} \\
(1.194)\end{array}$ & -0.111 & 0.132 & 0.068 & $\begin{array}{l}0.209^{*} \\
(1.233)\end{array}$ & 0.099 & -0.314 & -0.131 & 0.020 & 0.068 \\
\hline SRE & 0.086 & 0.11 & 0.019 & 0.051 & 0.025 & $\begin{array}{l}0.256^{* *} \\
(1.292)\end{array}$ & $\begin{array}{l}0.228^{* *} \\
(1.256)\end{array}$ & 0.069 & -0.520 & $\begin{array}{l}0.344^{* *} \\
(1.410)\end{array}$ & $\begin{array}{c}0.390 * * * \\
(1.477)\end{array}$ & $\begin{array}{l}0.296^{*} \\
(1.345)\end{array}$ \\
\hline RCC & 0.073 & 0.031 & $\begin{array}{c}0.153^{* * *} \\
(1.165)\end{array}$ & $\begin{array}{l}0.120 * * \\
(1.127)\end{array}$ & $\begin{array}{l}0.130^{* *} \\
(1.139)\end{array}$ & 0.046 & 0.042 & 0.047 & $\begin{array}{c}-0.432 * * * \\
(0.649)\end{array}$ & -0.122 & -0.083 & -0.104 \\
\hline
\end{tabular}


Table 5. Cont.

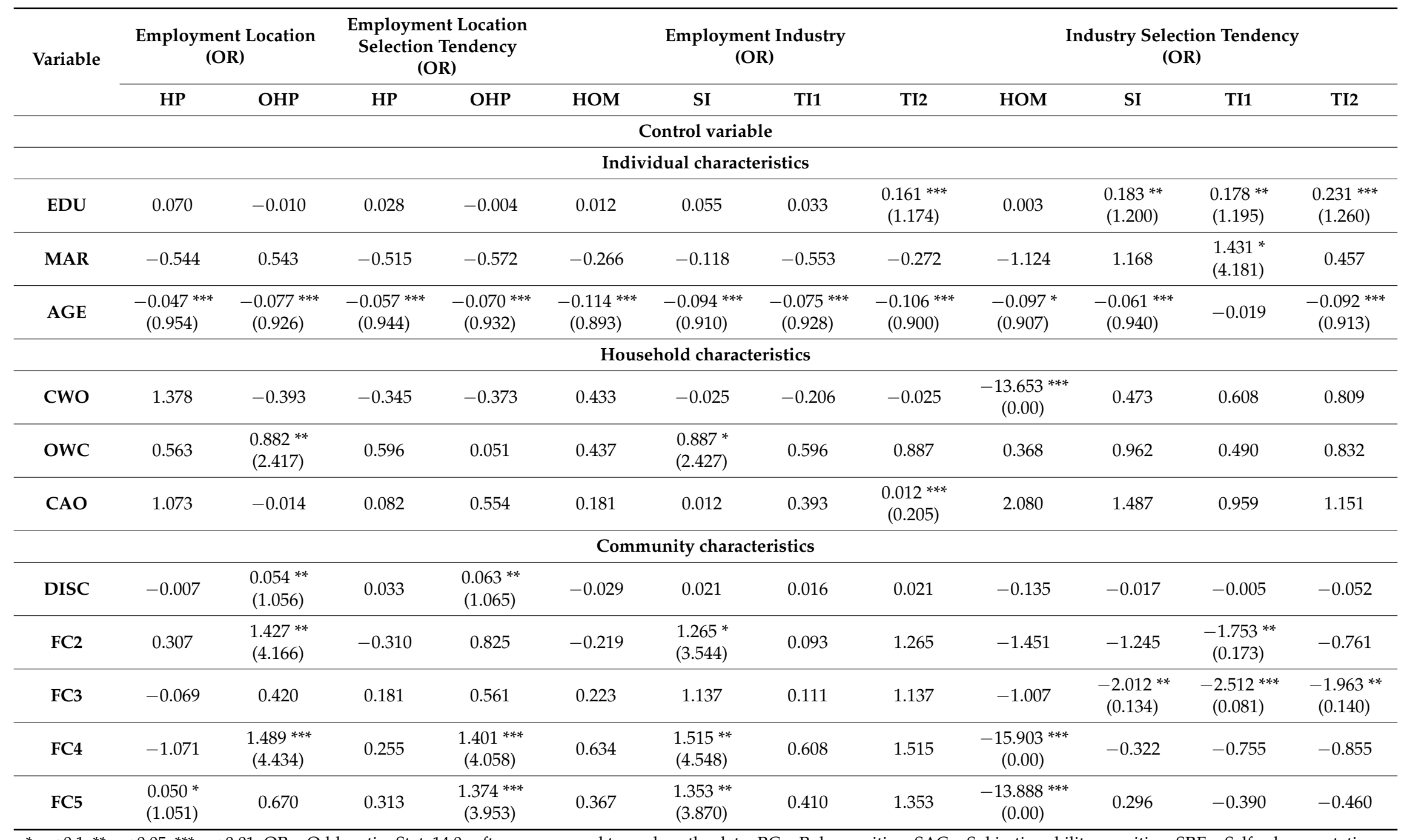

$* p<0.1, * * p<0.05, * * *<0.01$. OR = Odds ratio. Stata14.0 software was used to analyze the data. RC = Role cognition; SAC = Subjective ability cognition; SRE = Self-role expectations; $\mathrm{RCC}=$ Role conflict cognition; HP = home province but outside of home county; OHP = outside of home province. PI = unemployment $/$ staying at home, SI = secondary industry, TI1 = tertiary industry I, TI2 = tertiary industry II; CWO = elderly people and children in the family, OWC = elderly people and no children in the family, CAO = children and no elderly people in the family; FC2 = from county2, FC3 = from county3, FC4 = from county4, FC5 = from county5. 
At the same time, the robust model with inclusion of the control variables showed positive correlations between educational level and industry selection tendency, while age was significantly negatively related to almost all employment strategy selections. Meanwhile, family factors (whether there are elderly people or children in the family) were significantly correlated with some employment strategies of rural females, and social factors (the hometown) were also significantly related to the employment strategy selections of rural females, which indicates that there are obvious geographical differences in employment strategies.

\section{Discussion}

There are several similarities and differences between the findings from this study and the existing research results from Western countries:

In the past cross-cultural studies, China is considered to be a more masculine society, the previous study showed the sex-role attitudes and role cognition of Chinese females are quite different from those of Western females [36,37]. However, the results of this study show that Chinese rural women's role cognition tends to be close to Western women. In contrast to Western studies, the traditional concept of "breadwinning men and homemaking women" in Chinese society is more deep-rooted, and the social status of rural females is generally low. Rural females in China are often forced to adjust their employment expectations and stay at home, because they have to take care of their families. Thus, cognition of role conflict among rural females in China is more obvious. Based on the scale of the sex-role attitudes in the West, this study constructed a role cognition scale, which was suitable for rural females in China, and a measurement indicator of role conflicts was added to better measure role cognition of rural females in China.

Several scholars have found that groups with more liberal and equal role attitudes are more inclined to participate in labor [30,38,39], and females with more modern role cognition are more willing to engage in high-income or high-level occupations. Similar correlations were also found in this study, but in contrast, rural females with more modern role cognition were more inclined to work in areas far away from their hometown, or to engage in secondary and tertiary industries.

Existing studies have shown that, compared with males, females are more likely to avoid finding high-level occupations because of family stress [40]. Bertrand et al. found that females choose less competitive jobs in order to take care of their families [41]. The family may be the backbone of the career for males, but an obstacle to the career success of females. This study further adopted multivariate regression models and T-tests to explore conflicts between family roles and social roles quantitatively, so as to find out the significant differences between career expectations and career realities of rural females.

In addition, this study highlights several avenues for further research. In order to better reflect the wide range of female role cognition trends, we can consider increasing the sample size. The family is a crucial factor that affects individual gender equality cognition, as also shown in Western studies [30]. Meanwhile, liberalization of parents' gender cognition levels has a marked positive effect on the formation of equality concepts among their children. This study focused on female individuals, and the influence of female role cognition on family strategies is of interest for further study. Moreover, in general, role cognition changes with time; future studies should consider using panel data to further explore the relationship between role cognition and employment strategy selections of rural females.

\section{Conclusions and Implications}

Firstly, using survey data from a sample of 425 rural females from 400 rural households in Sichuan Province, this study constructed a role cognition scale by measuring subjective ability cognition, self-role expectations and role conflict cognition levels of rural female laborers. Differences between employment expectations and actual employment selections of rural female laborers were investigated. Furthermore, unordered multi-classification logistic regression models were constructed to explore 
the relationship between role cognition and employment strategy selections of rural female laborers. The main conclusions are as follows:

(1) Rural women's employment expectations are inconsistent with their actual employment. There were statistically significant differences between the expected employment industries and the actual employment industries of rural females, and the average value of the actual employment industries of rural females was significantly lower than that of the industry selection tendencies of rural females. Compared with farming at home, rural females are more willing to engage in secondary and tertiary industries. At the same time, there were also marked differences between the actual employment locations and the employment location selection tendencies of rural females; compared with working in the county, rural females are more willing to work in other provinces or other counties.

(2) Role cognition is significantly positively correlated with the career expectations of rural females, and role conflict cognition has an opposite influence on the career expectations and the actual jobs of rural females. Rural females who have more liberal and equal role cognition and perceive role conflicts more clearly, are more willing to work in areas far away from their hometowns or to engage in secondary and tertiary industries, but in fact, rural females with clearer perception of role conflicts generally choose to stay at home.

(3) Age has a noticeable negative impact on employment industry and employment location, and educational level is significantly positively correlated with industry selection. In this survey, $85 \%$ of the rural females only held a junior high school degree or less. Educational levels have seriously hindered the influence of agricultural feminization on women's self-development and the status of women in the development of rural society in the future.

According to the results of this study, in terms of rural policies, there is a need to broaden the rural employment channels, increase rural household incomes and to develop projects suitable for the participation of rural women, so that rural females can achieve their own career expectations while taking care of their family, or staying in rural areas.

Author Contributions: S.L. designed the research; D.X. collected the data; Y.S. analyzed the data and wrote the paper. All authors read and approved the final manuscript. We confirm that this manuscript has not been published elsewhere, and is not under consideration by another journal. Moreover, this manuscript was edited for proper English language, grammar, punctuation, spelling, and overall style by one or more of the highly qualified native English speaking editors at editage. The editage Company specializes in editing and proofreading scientific manuscripts for submission to peer-reviewed journals. We have prepared the completed text, and have the guidelines on copyright, and all the research meets the ethical guidelines. The names of all the co-authors have been included in the manuscript, and all authors have approved the manuscript and agree with submission to Sustainability.

Funding: This research was funded by National Natural Science Foundation of China (Grant No. 41571527;); Sichuan Center for Rural Development Research Project (Grant No. 01781912).

Conflicts of Interest: The authors declare no conflict of interest.

\section{References}

1. Xu, D.D.; Zhang, J.F.; Xie, F.T.; Liu, S.Q.; Cao, M.T.; Liu, E.L. Influential Factors in Employment Location Selection Based on "Push-Pull" Migration Theory-A Case Study in Three Gorges Reservoir Area in China. J. Mt. Sci. 2015, 12, 1562-1581. [CrossRef]

2. Knight, J.; Deng, Q.; Li, S. The puzzle of migrant labour shortage and rural labour surplus in China. China Econ. Rev. 2011, 22, 585-600. [CrossRef]

3. Liu, S.Q.; Zhang, H.Q.; Xie, F.T.; Guo, S.L. Current Situation and Influencing Factors of Pluriactivity in Mountainous and Hilly Rural Areas of Sichuan Province, China. J. Mt. Sci. 2013, 10, 445-454. [CrossRef]

4. Xie, F.T.; Xu, D.D.; Liu, S.Q.; Cao, M.T. The influence of gender and other characteristics on rural laborers' employment patterns in the mountainous and upland areas of Sichuan, China. J. Mt. Sci. 2015, 12, 769-782. [CrossRef]

5. Zhang, M. The impact of rural-urban migration: Case study on the Loess Plateau of Central China. China Inf. A J. Contemp. China Stud. 2010, 24, 169-189. [CrossRef] 
6. National Bureau of Statistics of China. Migrant Workers Monitoring Report in 2016; China Statistical Press: Beijing, China, 2017.

7. Xu, D.; Guo, S.; Xie, F.; Liu, S.; Cao, S. The impact of rural laborer migration and household structure on household land use arrangements in mountainous areas of Sichuan Province, China. Habitat Int. 2017, 70, 72-80. [CrossRef]

8. Xu, D.; Peng, L.; Liu, S.; Su, C.; Wang, X.; Chen, T. Influences of migrant work income on the poverty vulnerability disaster threatened area: A case study of the Three Gorges Reservoir area, China. Int. J. Disaster Risk Reduct. 2017, 22, 62-70. [CrossRef]

9. Xie, F.T. The Employment Transfer of Rural Female Laborers in the Mountainous and Upland Areas of Sichuan in the Urbanization Process; University of Chinese Academy of Sciences: Beijing, China, 2015.

10. Antman, F.M. Adult Child Migration and the Health of Elderly Parents Left Behind in Mexico. Soc. Sci. Electron. Publ. 2010, 100, 205-208. [CrossRef]

11. Zheng, L.; Wu, Y.X. Impact of parental migration on educational development of left-behind children: Evidence from western rural area of China. J. Beijing Norm. Univ. 2014, 242, 139-146.

12. National Women's Federation Task Force. Research Report on the Situation of Floating Children in Rural and Urban Areas Left Behind in Rural Areas in China. Chin. Women's Mov. 2013, 6, 30-34.

13. Han, W.L. The Structure of Migrant Rural Workers, the Motive of Backward Mobility and Its Policy Implications: An Analysis Based on the Survey Data of Mianyang, Nanchong and Suining. Southwest Financ. 2016, 1, 61-63.

14. Camlin, C.S.; Snow, R.C.; Hosegood, V. Gendered Patterns of Migration in Rural South Africa. Popul. Space Place 2014, 20, 528. [CrossRef]

15. Xu, L.F. A Study on the Problems of Aging, Labor Migration and Rural Family Support-A Case Study of a Rural Multiple-child Family in Village B. North Jiangsu. J. Shandong Agric. Eng. Coll. 2015, 1, 1-3.

16. Bolzendahl, C.I.; Myers, D.J. Feminist Attitudes and Support for Gender Equality: Opinion Change in Women and Men, 1974-1998. Soc. Forces 2004, 83, 759-789. [CrossRef]

17. Harris, R.J.; Firestone, J.M. Changes in Predictors of Gender Role Ideologies Among Women: A Multivariate Analysis. Sex Roles 1998, 38, 239-252. [CrossRef]

18. Twenge, J.M. Changes in masculine and feminine traits over time: A meta-analysis. Sex Roles 1997, 36, 305-325. [CrossRef]

19. Farré, L.; Vella, F. The Intergenerational Transmission of Gender Role Attitudes and its Implications for Female Labour Force Participation. Economica 2013, 80, 219-247. [CrossRef]

20. Mclanahan, S.S.; Kelly, E.L. The Feminization of Poverty. J. Econ. Issues 1997, 9, 21-40. [CrossRef]

21. Judge, T.A.; Livingston, B.A. Is the gap more than gender? A longitudinal analysis of gender, gender role orientation, and earnings. J. Appl. Psychol. 2008, 93, 994-1012. [CrossRef] [PubMed]

22. Eccles; Adler, T.F.; Futterman, R.; Goff, S.B.; Kaczala, C.M.; Meece, J.; Midgley, C. Achievement and achievement motives: Psychological and sociological approaches. Psychol. Sch. 1983, 1, 173-178.

23. Mcbroom, W.H. Longitudinal change in sex role orientations: Differences between men and women. Sex Roles 1987, 16, 439-452. [CrossRef]

24. Houser, B.B.; Beckman, L.J. Background characteristics and women's dual-role attitudes. Sex Roles 1980, 6, 355-366. [CrossRef]

25. Corrigall, E.A.; Konrad, A.M. Gender Role Attitudes and Careers: A Longitudinal Study. Sex Roles 2007, 56, 847-855. [CrossRef]

26. Wu, H.M. Self-Efficacy, Work-Family Conflict, Social Support, Gender Role Attitude and Role Model as Antecedents of Career Aspiration among Women in Middle Management; Universiti Putra Malaysia: Kuala Lumpur, Malaysia, 2007.

27. Press Office of China. Human Resources in China; Sichuan Labor Security: Sichuan, China, 2010; pp. 13-24.

28. Cao, M.; Xu, D.; Xie, F.; Liu, E.; Liu, S. The influence factors analysis of households' poverty vulnerability in southwest ethnic areas of China based on the hierarchical linear model: A case study of Liangshan Yi autonomous prefecture. Appl. Geogr. 2016, 66, 144-152. [CrossRef]

29. Adachi, T. Work-family planning and gender role attitudes among youth. Int. J. Adolesc. Youth 2017. [CrossRef]

30. Thornton, A.; Alwin, D.F.; Camburn, D. Cause and Consequences of Sex Role Attitudes and Attitude Change. Am. Sociol. Rev. 1983, 48, 211-227. [CrossRef] [PubMed] 
31. Rozelle, S. Stagnation Without Equity: Patterns of Growth and Inequality in China's Rural Economy. China J. 1996, 35, 63-92. [CrossRef]

32. Xu, X.Y.; Li, Z.Z.; Chen, L. An Factor Analysis of Gender Equality Cognition in the Field of Employment -A Research Based on the Survey Data in Shanghai. Fudan J. (Soc. Sci.) 2010, 4, 16-25.

33. Yang, T.; Jin, X.Y. The Impact of Resource Endowment and the Social-Security System on Migrant Workers, Willingness of Land Disposal From the perspective rational choice theory. China Rural Surv. 2015, 4, 16-25.

34. Ma, D.S.; Wang, L.Q. On the Relations between Rural Labor Transfer and Farmers' Income Increase. Commer. Res. 2008, 11, 151-154.

35. Wang, D.P.; Peng, J.Q.; Yan, Z. Employment and transfer status of female labor force in rural China. Asian Agric. Res. 2009, 37, 4-9.

36. Fernandez, D.R.; Carlson, D.S.; Stepina, L.P.; Nicholson, J.D. Hofstede's Country Classification 25 Years Later. J. Soc. Psychol. 1997, 137, 43-54. [CrossRef]

37. Chang, L. Gender Role Egalitarian Attitudes in Beijing, Hong Kong, Florida, and Michigan. J. Cross-Cult. Psychol. 2016, 30, 722-741. [CrossRef]

38. Jin, C.A. Research on the Issues of Contemporary Chinese Women's Employment; Northeast Normal University: Changchun, China, 2012.

39. Li, J.F. Reasons for Female Employment and Development Dilemma. Popul. J. 2002, 5, 56-59.

40. Silbermann, R. Gender Roles, Work-Life Balance, and Running for Office. Q. J. Polit. Sci. 2015, 10, $123-153$. [CrossRef]

41. Bertrand, M.; Goldin, C.; Katz, L.F. Dynamics of the Gender Gap for Young Professionals in the Financial and Corporate Sectors. Am. Econ. J. Appl. Econ. 2010, 2, 228-255. [CrossRef]

(C) 2019 by the authors. Licensee MDPI, Basel, Switzerland. This article is an open access article distributed under the terms and conditions of the Creative Commons Attribution (CC BY) license (http:/ / creativecommons.org/licenses/by/4.0/). 